\title{
Manajemen Privasi Jemaat Ahmadiyah di Kota Semarang
}

\author{
Muhammad Syaoki \\ Program Studi Komunikasi Penyiaran Islam, Fakultas Agama Islam \\ Universitas Muhammadiyah Mataram,83115, Indonesia \\ okiepluralist@gmail.com
}

Riwayat Artikel:

Diterima Desember 2017

Direvisi Januari 2018

Disetujui Februari 2018

\begin{abstract}
Abstrak: Penelitian ini bertujuan untuk menggambarkan perilaku komunikasi Jemaat Ahmadiyah dalam posisi mereka sebagai kelompok yang dilarang menyebarkan ajarannya. Dengan menggunakan teori manajemen privasi komunikasi yang diperkenalkan oleh Sandra Petronio, penelitian ini berusaha menjelaskan proses dialektis yang dilakukan oleh jemaat Ahmadiyah di kota Semarang ketika berinteraksi dengan banyak orang dalam kehidupan sehari-hari. Hasil penelitian ini menunjukkan bahwa Jemaat Ahmadiyah melakukan pembukaan informasi privat dengan komunikasi langsung dan tidak langsung. Jemaat Ahmadiyah melakukan pembukaan informasi privat bertujuan untuk mengklarifikasi kesalahpahaman ghair tentang Ahmadiyah. Jemaat Ahmadiyah kota Semarang cenderung menutup informasi privat mereka kepada keluarga dan teman ketika mereka baru berbai'at. Mereka juga menutup informasi privat kepada orang-orang Muhammadiyah, serta kepada kelompok-kelompok Islam garis keras, seperti FPI, LDII, termasuk juga kader PKS. Tetapi mereka membuka informasi mengenai Ahmadiyah kepada orang-orang dari kalangan NU, dan aparatur pemerintah.
\end{abstract}

\begin{abstract}
This research aims to describe the behavior of Ahmadiyyah community in their position as a group that is prohibited from spreading its teachings. Using the communication privacy management theory introduced by Sandra Petronio, this research attempts to explain the dialectical process undertaken by the Ahmadiyah community in the Semarang city while interacting with many people in everyday life. The results of this study indicate that the Ahmadiyyah community conducts the opening of private information with direct and indirect communication. The Ahmadiyah community conducted the opening of private information aimed to clarify misunderstanding about "ghair" of Ahmadiyah. The Ahmadiyah community of Semarang tends to hide their private information from family and friends when they are newly banned. They also hide private informations to Muhammadiyah people, as well as to hard-line Islamic groups, such as FPI, LDII, as well as PKS cadres. But they do not hide information about Ahmadiyyah to people from the NU, and the government apparatus.
\end{abstract}

Kata Kunci:

Manajemen Privasi Komunikasi,

Pembukaan,

Keywords:

Ahmadiya,

Communication Privacy Management, Opening,

Closure.

\section{Pendahuluan}

Setiap orang memiliki informasi privat dan informasi publik terkait eksistensi dirinya di tengah lingkungannya. Teori Manajemen Privasi Komunikasi (Communication Privacy Management) yang diperkenalkan Sandra Petronio tertarik untuk menjelaskan proses-proses negosiasi orang seputar pembukaan informasi privat. ${ }^{1}$ Sistem manajemen privasi yang ditawarkan dalam teori manajemen privasi komunikasi ini menjadi acuan dalam mengkoordinasikan batasbatas privasi tentang apa yang diungkapkan dan apa yang dianggap pribadi oleh seseorang.

\footnotetext{
${ }^{1}$ Petronio, Sandra, 2002, Boundries of Privacy: Dialectic of Disclosure, New York: New York University Press, h, 3.
} 
Dalam manajemen privasi komunikasi, pembukaan pribadi didefinisikan tiga cara; pertama, pembukaan pribadi memberikan penekanan lebih pada isi personal. Kedua teori ini memberi penekanan lebih pada substansi dari pembukaan, atau pada hal-hal yang dianggap pribadi, manajemen privasi komunikasi mempelajari bagaimana orang melakukan pembukaan melalui sistem yang didasarkan pada aturan. Ketiga pembukaan hanyalah berkaitan dengan diri sendiri. Untuk dapat benar-benar memahami dalam dan luasnya sebuah pembukaan, manajemen privasi komunikasi tidak hanya membatasi proses ini kepada diri, tapi memperluasnya hingga mencakup banyak level termasuk pembukaan diri dan kelompok.

Oleh karenanya, teori ini menawarkan sistem manajemen privasi yang mengidentifikasi caracara batasan privasi dikoordinasikan antarindividu. Manajemen privasi komunikasi mencapai tujuan dengan mengajukan lima asumsi dasar: Informasi privat, batasan privat, kontrol dan kepemilikan, sistem manajemen berdasarkan aturan, dialektika manajemen. Setiap asumsi yang disajikan dalam teori ini menjelaskan langkah dan tahapan yang bisa dilakukan seseorang dalam mengatur informasi privat mereka dalam interaksi sosial.

Teori manajemen privasi komunikasi menjadi sebuah penjelasan untuk manajemen informasi yang dimiliki Jemaat Ahmadiyah. Teori ini dibutuhkan untuk menjelaskan berbagai gangguan sehari-hari akibat dari stigma negatif yang dialamatkan kepada Jemaat Ahmadiyah. Teori ini berguna untuk memahami kecenderungan antara pembukaan informasi dan privasi dalam sebuah hubungan hubungan sosial yang dilakukan oleh Jemaat Ahmadiyah.

Jemaat Ahmadiyah merupakan sebuah gerakan kegamaan yang didirikan oleh Mirza Ghulam Ahmad di Qadian sebuah desa kecil di India pada tahun 1835 Masehi. Gerakan ini muncul sebagai respon atas upaya kristenisasi dengan kedok kolonialisasi yang dilakukan oleh Inggris. Kedatangan Ahmadiyah ke Indonesia terbilang cukup lama yakni sejak tahun 1920 bahkan Ahmadiyah dalam sejarahnya peranah turut serta dalam proses memperjuangkan kemerdekan dari tangan para penjajah. ${ }^{2}$

Hanya saja pada medio 2002 sampai 2006 Jemaat Ahmadiyah banyak mendapat penentangan dari kelompok Islam mainstream. Persoalan teologis menjadi alasan utama penolakan terhadap Jemaat Ahmadiyah. Jemaat Ahmadiyah yang meyakini Mirza Ghulam Ahmad sebagai nabi dianggap menyimpang oleh kalangan Islam mainstream. ${ }^{3}$ Karena menurut mereka konsep kenabian sudah berakhir seirng dengan wafatnya nabi Muhammad, oleh karena itu tidak ada lagi nabi setelahnya.

Dalam rangka merespon kondisi ini Majelis Ulama Indonesia (MUI) kemudian mengeluarkan fatwa Nomor: 11/MUNAS VII/MUI/15/2005 tentang larangan menyebarkan faham Ahmadiyah di seluruh Indonesia dan membekukan organisasi serta memerintahkan untuk menutup semua tempat kegiatannya. Meskipun secara teologis fatwa ini dinalai dapat membatasi penyimpanganpenyimpangan dalam Islam, namun secara sosial-politik fatwa tersebut dapat menyulut aksi anarkis terhadap Jemaat Ahmadiyah di berbagai daerah.

Faktanya, setelah fatwa tentang larangan menyebarkan faham Ahmadiyah dikeluarkan, maka kemudian muncul aksi pembakaran serta pengusiran Jemaat Ahmadiyah di berbagai tempat. Di Lombok misalnya terjadi pengusiran yang mengakibatkan sekitar 23 kepala keluarga harus rela meninggalkan kampung halaman mereka karena masyarakat setempat yang mayoritas muslim sunni menolak kehadiran mereka di kampung tersebut.

\footnotetext{
${ }^{2}$ Zulkarnain, Iskandar, 2005, Gerakan Ahmadiyah di Indonesia, Yogyakarta, LkiS, h.311.

${ }^{3}$ Pengertian Islam mainstream (arus utama Islam) di Indonesia mengarah pada kelompok-kelompok Islam yang dianut oleh sebagian besar masyarakat Islam serta dijadikan referensi dalam berbagai urusan yang berhubungan dengan hukum-hukum dalam kasus umat Islam di Indonesia masa kini. Mainstream atau ortodoksi dalam istilah Martin van Bruinessen diwakili oleh Majelis Ulama Indonesia (MUI), termasuk juga organisasi-organisasi kemasyarakatan yang ada di dalamnya. Lihat Dewi Nurul Maliki, "Resistensi Kelompok Minorotas Keagamaan Jemaat Ahmadiyah Indonesia”, dalam Jurnal Ilmu Sosial dan Politik Volume 14, Nomor 1, Juli 2010 (47-62) Universitas Gajah Mada Yogyakarta.
} 
Dalam catatan Moh. Asyiq Amrullah dkk (2010) akibat tindakan massa pada 4 Februari 2006 itu 23 rumah Jemaat Ahmadiyah dirusak dan dibakar. Kejadian tersebut memaksa mereka meninggalkan tempat tinggalnya yang berada di Dusun Ketapang, Desa Gegelang, Kecamatan Lingsar, mereka sampai saat ini menjadi penghuni tempat pengungsian di Asrama Transito Jalan Pariwisata Mataram hingga kini. ${ }^{4}$

Kasus yang menimpa Jemaat Ahmadiyah di Kuningan, Jawa Barat juga tidak jauh berbeda. Mengutip laporan yang ditulis oleh Rosyidin dan Ali Mursyid di daerah Kuningan Jawa Barat terjadi peristiwa pembakaran mushalla at-Taqwa milik Jemaat Ahmadiyah oleh sekelompok warga. Setelah melakukan pembakaran mushalla, aksi warga kemudian berlanjut hingga pada penyegelan aset-aset yang dimiliki Jemaat Ahmadiyah. Di samping itu Jemaat Ahmadiyah juga tidak dapat melangsungkan pernikahan, karena Kantor Urusan Agama (KUA) setempat menolak menikahkan selama mereka masih menganut kepercayaan Ahmadiyah. ${ }^{5}$

Persoalan muncul ketika di satu sisi Jemaat Ahmadiyah berharap dapat mengenalkan Ahmadiyah kepada semua orang, namun di sisi lain Ahmadiyah justru dilarang menyebarkan ajarannya dalam segala bentuknya. Kondisi ini membuat Jemaat Ahmadiyah di kota semarang terlibat dalam pilihan-pilihan yang dilematis. Oleh karena itu dibutuhkan sebuah strategi yang tepat dalam rangka merespon pilihan-pilihan yang dilematis tersebut.

Penelitian ini tertarik untuk menjelaskan proses-proses manajemen informasi yang dilakukan oleh Jemaat Ahmadiyah kota Semarang dalam rangka merespon fatwa MUI yang melarang setiap bentuk penyebaran ajaran Ahmadiyah. Peneliti berusaha menjawab pertanyaan terkait kenapa Jemaat Ahmadiyah kota Semarang membuka atau menutup informasi privat mereka, bentuk pengungkapan informasi privat, serta bagaimana cara mereka mengontrol informasi privat.

\section{Kajian Pustaka}

\section{A. Komunitas Ahmadiyah di Kota Semarang}

Jemaat Ahmadiyah kota Semarang beraliran Qadian. Aliran Qadian meyakini Mirza Ghulam Ahmad sebagai mujaddid sekaligus sebagai seorang Nabi. Doktrin inilah yang membuat Ahmadiyah aliran Qadian khususnya, banyak mendapat penentangan dari kalangan Islam mainstream yang notebene meyakini bahwa tidak ada nabi lagi setelah Nabi Muhammad.

Kedatangan Jemaat Ahmadiyah di Kota Semarang sudah dimulai sekitar tahun 1963, dibawa oleh dua orang mubaligh yang didatangkan oleh PB Jemaat Ahmadiyah Indonesia ke Semarang. Mubaligh tersebut bernama Ahmad Dimyati dan Suryawarman, mereka merupakan orang asli Semarang yang masuk Ahmadiyah karena ketakjubannya dengan dalil-dalil akan kematian Isa dan atas perilaku para pemeluk Ahmadiyah yang cenderung shalih. ${ }^{6}$

Dalam gerakannya Mirza Ghulam Ahmad mengaku sebagai seorang nabi yang diberikan tugas meneruskan perjuangan nabi Muhammad. Doktrin inilah yang banyak ditentang oleh kalangan Islam mainstream. Karena bagi mereka doktrin tentang kenabian sudah final dan berakhir pada masa nabi Muhammad.

Imbas dari penolakan ini di berbagai tempat di Indoenasia Jemaat Ahmadiyah mengalami tindak kekerasan baik berupa kekerasan fisik berupa pengusiran, pembakaran tempat ibadah maupun kekerasan mental berupa pengucilan dari lingkungan sosial.

\footnotetext{
${ }^{4}$ Amrullah, Moh. Asyiq, dkk, 2010, "Dampak Sosial Kekerasan Terhadap Jamaah Ahmadiyah di Lombok dan Upaya Resolusi Konflik", Jurnal Penelitian Keislaman, Vol.6 (6), 54-67.

${ }^{5}$ Rosyidin dan Mursyid Ali, 2007, "Diskriminasi Hak Sipil Minoritas: Pelarangan Pencatatan Pernikahan jemaat Ahmadiyah Kuningan" dalam Ahmad Suaedy dkk. Politisasi Agama dan Konflik Komunal: Beberapa Isu Penting di Indonesia, Jakarta: The Wahid Institute, 4975 .

${ }^{6}$ Wawancara dengan Arif Syafi'i sebagai Ketua Jemaat Ahmadiyah Jawa Tengah, Semarang: 17 Januari dan 3 Maret 2016 jam 18.33 WIB.
} 
Di kota Semarang keberadaan Jemaat Ahmadiyah relatif aman. Meskipun tidak mendapat ancaman berupa kekerasan fisik namun keberadaan mereka belum sepenuhnya diterima oleh masyarakat. Dalam beberapa kasus mereka kerap dibedakan dengan masyarakat Islam pada umumnya. Perlakuan diskriminatif ini kerap mereka dapatkan di lingkungan sekitar tempat tinggal mereka maupun di lingkungan kerja.

Perlakuan-perlakuan diskrimintaif itu membuat Jemaat Ahmadiyah di kota Semarang melakukan pengelolaan informasi menganai Ahmadiyah. informasi itu mereka kelola dalam rangka merespon fatwa yang dilakukan oleh MUI terkait pelarangan penyebaran ajaran Ahmadiyah dalam berbagai bentuknya.

\section{Kajian Teoritik}

Teori Manajemen Privasi Komunikasi (Communication Privacy Management) yang diperkenalkan Sandra Petronio tertarik untuk menjelaskan proses-proses negosiasi orang seputar pembukaan informasi privat. Sistem manajemen privasi yang ditawarkan dalam teori manajemen privasi komunikasi ini menjadi acuan dalam mengkoordinasikan batas-batas privasi tentang apa yang diungkapkan dan apa yang dianggap pribadi oleh seseorang. ${ }^{7}$

Dalam teori manajemen privasi komunikasi, pembukaan pribadi didefinisikan melalui tiga cara; pertama, pembukaan pribadi memberikan penekanan lebih pada isi personal, kedua teori ini memberi penekanan lebih pada substansi dari pembukaan, atau pada hal-hal yang dianggap pribadi, manajemen privasi komunikasi mempelajari bagaimana orang melakukan pembukaan melalui sistem yang didasarkan pada aturan. Kemudian yang ketiga adalah bahwa pembukaan hanyalah berkaitan dengan diri sendiri. Untuk dapat benar-benar memahami dalam dan luasnya sebuah pembukaan, manajemen privasi komunikasi tidak hanya membatasi proses ini kepada diri, tapi memperluasnya hingga mencakup banyak level termasuk pembukaan diri dan kelompok.

Oleh karenanya, teori ini menawarkan sistem manajemen privasi yang mengidentifikasi caracara batasan privasi dikoordinasikan antarindividu. Manajemen privasi komunikasi mencapai tujuan dengan mengajukan lima asumsi dasar: Informasi privat, batasan privat, kontrol dan kepemilikan, sistem manajemen berdasarkan aturan, dialektika manajemen. Setiap asumsi yang disajikan dalam teori ini menjelaskan langkah dan tahapan yang bisa dilakukan seseorang dalam mengatur informasi privat mereka dalam interaksi sosial.

\section{A. Informasi Privat}

Asumsi ini merujuk pada cara berpikir mengenai pembukaan atau pengungkapan informasi privat. Banyak peneliti telah mengombinasikan pembukaan diri dengan keintiman seakan keduanya merupakan hal yang ekuivalen walaupun dua hal ini merupakan dua konsep yang berbeda. Petronio berpendapat bahwa "keintiman (intimacy) adalah perasaan atau keadaan mengetahui seseorang dengan cara mendalam dalam ciri-ciri fisik, psikologi, emosional, dan prilaku karena orang ini penting dalam kehidupan seseorang. Pembukaan pribadi, sebaliknya, tertarik dengan proses bercerita dan merefleksikan isi dari informasi yang privat mengenai orang lain dan kita". 8

West dan Turner mengatakan bahwa "apa yang membuat suatu hal privat adalah sebagian besar karena pentingnya hal tersebut bagi konsepsi kita akan diri kita sendiri dan bagi hubungan kita dengan orang lain". Orang mendefinisikan informasi privat sebagai informasi tentang hal-hal yang sangat berarti bagi mereka. Dalam penelitian ini yang dimaksud dengan informasi privat yaitu segala informasi tentang diri mereka yang jika diungkapkan ke publik atau orang di luar

\footnotetext{
${ }^{7}$ Petronio, Boundries, h. 3.

${ }^{8}$ West, Richard and Lynn H.G.Turner, 2010, Introducing Comunication Theory: Analysis and Aplication, New York: McGraw Hill, h. 225 .
} 
kelompok mereka maka akan mengundang reaksi dalam bentuk diskriminasi atau perlakuanperlakuan buruk lainnya. ${ }^{9}$

\section{B. Batasan Privat}

Manajemen privasi komunikasi bergantung terhadap metafora batasan dalam menjelaskan bahwa ada garis antara bersifat publik serta bersikap privat. Pada satu sisi batasan ini, seseorang menyimpan informasi privat untuk diri mereka sendiri. Pada sisi yang lain, seseorang membuka informasi privat kepada orang lain dalam relasi sosial dengan mereka. Ketika informasi privat dibagikan batasan di sekitarnya disebut batasan kolektif (collective boundary), sebab informasi tersebut menjadi milik hubungan yang ada. Ketika informasi privat disimpan oleh seorang individu dan tidak dibuka, maka batasannya disebut batasan personal (personal boundary). ${ }^{10}$

Menurut Petronio, individu-individu yang terlibat dalam hubungan terus mengatur batasanbatasan antara apa yang umum dan pribadi, antara perasaan-perasaan yang ingin mereka bagi. Kadang-kadang batasannya dapat ditembus, yang berarti bahwa informasi tertentu dapat diungkapkan; namun di saat yang lain, batasan tersebut tidak dapat ditembus yang berarti informasi tidak pernah dibagi. Mempertahankan batasan tertutup dapat memberikan otonomi dan keamanan yang lebih kuat, sedangkan pembukaan batasan dapat memberikan kedekatan dan pembagian yang lebih besar, tetapi juga kelemahan yang lebih besar.

Dalam penelitian ini batasan privat yang dimaksud adalah garis pembatas antara informasi yang dianggap sebagai privasi dan bukan privasi oleh Jemaat Ahmadiyah. Dalam mengelola batsan tersebut jemaat Ahmadiyah terlibat dalam pilihan membuka maupun menutup batasannya. Ketika batasan dibuka maka informasi tersebut berubah dari informasi privat menjadi informasi publik. Sebaliknya, ketika betasan tersebut ditutup maka informasi tersebut tetap menjadi informasi privat.

\section{Kontrol dan Kepemilikan}

Asumsi ini bergantung pada ide bahwa orang merasa mereka punya informasi privat mengenai diri mereka sendiri. Sebagai pemilik informasi, mereka percaya bahwa mereka harus ada dalam posisi untuk mengontrol siapa saja (jika memang ada) yang boleh mengakses informasi ini. Kontrol dan kepemilikan di sini terkait dengan otoritas yang dimiliki oleh Jemaat Ahmadiyah terkait dengan informasi privat mereka. ${ }^{11}$

\section{Sistem Manajemen Berdasarkan Aturan}

Sistem ini merupakan kerangka untuk memahami keputusan yang dibuat seseorang mengenai informasi privat. Sistem ini memungkinkan pengelolaan dalam level individu maupun kolektif yang terdiri atas tiga proses yaitu: karakteristik aturan privasi, koordinasi batasan, dan turbulensi batasan. $^{12}$

\section{E. Dialektika Manajemen}

Asumsi ini berfokus pada ketegangan-ketegangan antara keinginan untuk mengungkapkan informasi privat atau keinginan untuk menutupinya. Tesis dasar dari teori ini menurut Petronio didasarkan pada kesatuan dialektika merujuk pada ketegangan-ketegangan yang dialami seseorang sebagai akibat dari kontradiksi dan oposisi. Dalam hal ini dialektika manajemen berkaitan dengan keinginan Jemaat Ahmadiyah untuk mengungkapkan informasi privat mereka di satu sisi, namun di sisi lain mereka juga ingin menutupinya. ${ }^{13}$

Teori manajemen privasi komunikasi menjadi sebuah penjelasan untuk manajemen informasi yang dimiliki Jemaat Ahmadiyah. Teori ini dibutuhkan untuk menjelaskan berbagai gangguan

\footnotetext{
${ }^{9}$ West, Richard and Lynn H.G.Turner, 2010, h. 225

${ }^{10} \mathrm{Ibid}$, h. 225

${ }^{11} \mathrm{Ibid}, \mathrm{h} .226$.

${ }^{12}$ West, Richard and Lynn H.G.Turner, 2010, h. 227.

${ }^{13} \mathrm{Ibid}$, h. 227.
} 
sehari-hari akibat dari stigma negatif yang dialamatkan kepada Jemaat Ahmadiyah. Teori ini berguna untuk memahami kecenderungan antara pembukaan informasi dan privasi dalam sebuah hubungan hubungan sosial yang dilakukan oleh Jemaat Ahmadiyah.

\section{Metode Penelitian}

\section{A. Pendekatan dan Jenis Penelitian}

Penelitian ini merupakan jenis penelitian kualitatif dengan menggunakan pendekatan fenomenologis. Dalam penelitian ini peneliti mewawancarai beberapa orang Jemaat Ahmadiyah, peneliti bertanya seputar pengalaman mereka menjadi Jemaat Ahmadiyah, bagaimana mereka mengkomunikasikan informasi mengenai status mereka sebagai anggota Jemaat Ahmadiyah serta doktrin-doktrin yang ada dalam jemaat Ahmadiyah.

Pertama, peneliti melakukan wawancara dengan Alvan Pahuluan, ia merupakan seorang anggota Jemaat Ahmadiyah kota Semarang yang berasal dari Padang, Sumaera Barat. Saat ini ia sedang kuliah di program Pascasarjana Universitas Diponegoro Semarang.

Kepada peneliti ia menceritakan pengalamannya sebagai seorang ahmadi. ia sejak lahir merupakan seorang ahmadi, karena kedua orang tuanya juga seorang ahmadi. Pengalamannya menjadi seorang ahmadi cukup beragam, ia mengaku sering mendapatkan perlakuan diskrimintaif dari orang-orang di sekitarnya. Namun ada juga orang-orang yang menaruh simpati terhadapnya sebagai seorang ahmadi. ${ }^{14}$

Selanjutnya Alvan juga mengaku sering membuka informasi mengenai Ahmadiyah kepada teman-temannya, hanya saja pembukaan informasi tidak dilakukan secara langsung. Ia membuka informasi tentang Ahmadiyah kepada ghair dengan cara menunjukkan perilaku-perilaku yang menggambarkan bahwa ia adalah seorang ahmadi seperti dengan tidak shalat kecuali dengan sesama anggota Jemaat Ahmadiyah. Alvan mengatakan ketika ia kuliah ia rela menempuh jarak hingga puluhan kilometer hanya untuk dapat shalat jumaat dengan sesama anggota Jemaat. ${ }^{15}$

Selama kuliah di Universitas Diponegoro Semarang Alvan mengatakan bahwa temantemannya belum mengetahui bahwa ia adalah seorang ahmadi. Hal itu disebabkan karena komunikasinya dengan teman-teman relatif tidak terlalu intens karena hubungannya hanya sebatas di ruang kelas saja. Setelah perkuliahan brakhir mereka pulang ke rumahnya masing-masing. Dalam hatinya ia mengaku ada keinginan untuk mengungkapkan kepada teman-teman tentang identitasnya sebagai Jemaat Ahmadiyah. Namun ia mengatakan masih menunggu saat yang tepat untuk melakukan pengungkapan diri. ${ }^{16}$

Selain ini peneliti juga melakukan wawancara dengan Endang Syafi'i ia merupakan Ketua Lajnah Imailah (organisasi perempuan Jemaat Ahmadiyah). wawancara dilakukan di Masjid Nusrat Jahan setelah acara nonton bersama khutbah khalifah.

Kepada penelitia ia mengatakan awalnya bukan merupakan seorang ahmadi, namun ia mulai berkenalan dengan Ahmadiyah ketika dilamar oleh seorang pria ahmadi bernama Arif Syafi'i. Ia kemudian berbai' at beberapa jam sebelum melangsungkan akad nikah. Dalam ajaran Ahmadiyah seorang non-ahmadi harus berbai'at terlebih dahulu sebelum menikah dengan orang ahmadi. ${ }^{17}$

Pada tahun 1980 Endang bersama keluarga pindah dari Surabaya ke Semarang. Awalnya tetangga belum mengetahui kalau ia sekeluarga merupakan orang Ahmadiyah, namun setelah beberapa lama ia kemudian mengungkapkan kepada tetangganya bahwa ia sekeluarga adalah

\footnotetext{
${ }^{14}$ Pahuluan, Alvan, 2016, (wawancara dengan Alvan Pahuluan sebagai anggota Jemaat Ahmadiyah), Semarang: 30 Januari 2016 jam 18.13 WIB.

${ }^{15} \mathrm{Ibid}$, wawancara.

${ }^{16}$ Pahuluan, Alvan, 2016, (wawancara dengan Alvan Pahuluan sebagai anggota Jemaat Ahmadiyah), Semarang: 30 Januari 2016 jam 18.13 WIB.

${ }^{17}$ Wawancara dengan Endang Syafi'i sebagai Ketua Lajnah Imailah, Semarang: 7 Februari 2016 jam 21.18 WIB.
} 
orang Ahmadiyah. Meskipun demikian Endang mengaku tidak mendapat respon yang negatif ketika mengungkapkan informasi tentang Ahmadiyah. ${ }^{18}$

Endang sering melakukan tabligh kepada orang-orang ghair. Tabligh dilakukan dengan cara menceritakan tentang Ahmadiyah beserta ajaran-ajarannya kepada teman-temannya. Beberapa orang merasa tertarik untuk mengetahui lebih jauh tentang Ahmadiyah, meski tidak sedikit juga yang justru mengabaikannya. Pengungkapan itu dilakukan ketika ada pertemuan dengan ibu-ibu anggota PKK di Kelurahan Menjangan, serta ketika ada tetangga yang datang ke rumahnya bersilaturrahmi, atau sebaliknya ketika ia datang bersilaturrahmi ke rumah tentangganya. ${ }^{19}$

Endang mengatakan bahwa ia sepenuhnya menyadari ada resiko yang akan ia dapatkan ketika melakukan pengungkapan tentang Ahmadiyah. Pernah ada beberapa teman yang justru menjauhinya setelah ia melakukan pengungkapan tentang Ahmadiyah, namun ada juga yang malah menjadi semakin akrab dengannya. Namun hal itu tidak membuat ia jera, karena ia melakukannya semata-mata karena Allah. ${ }^{20}$

Informan selanjutnya bernama Dodik Setiawan, ia awalnya merupakan salah satu anggota Jamaah Ansorutauhid pimpinan Abu Bakar Baasyir. Dalam organisasi tersebut ia mengaku banyak didoktrin mengenai kesesatan Ahmadiyah. Hal ini justru membuatnya tertarik untuk mengetahui lebih jauh tentang Ahmadiyah, sehingga pada tahun 1996 ia resmi masuk menjadi anggota Jemaat Ahmadiyah. ${ }^{21}$

Setelah masuk Ahmadiyah, ia tidak mengatakan secara langsung kepada keluarganya perihal dirinya yang sudah menjadi seorang ahmadi. ia hanya menunjukkan lewat perubahan sikap dan tingkah laku. Setelah masuk Ahmadiyah ia menjadi lebih sering melaksanakan shalat tahajjud, dhuha, dan shalat-shalat sunnat lannya. Di samping itu ia juga setiap hari Kamis mengikuti acara pengajian yang diadakan di Masjid Nusrat Jahan. ${ }^{22}$

Dodik melakukan dua cara pengungkapan identitas kepada teman-temannya, pertama, untuk teman-teman yang menurutnya cukup terbuka dan toleran, maka ia akan mengungkapkan langsing identitasnya sebagai Jemaat Ahmadiyah. Orang-orang dari kalangan Nahdhatul Ulama menurutnya termasuk dalam kelompok ini. ${ }^{23}$

Sementara untuk orang-orang yang dianggapnya tertutup dan tidak toleran, ia lebih memilih mengungkapkan identitasnya dengan cara menujukkan tingkah laku yang baik, tujuannya adalah untuk membangun persepsi yang baik sehingga orang-orang yang dinilai tidak toleran tersebut memahami bahwa tidak ada perbedaan antara Ahmadiyah dengan ghair Ahmadiyah terutama sekali dalam perilaku, sikap, dan cara mereka bergaul. Orang-orang yang dalam kelompok ini menurutnya adalah orang Muhammadiyah dan orang-orang dari kelompok Islam garis keras. ${ }^{24}$

\section{Penyajian dan Analisis Data}

\section{A. Alasan Membuka Informasi Privat}

Jemaat Ahmadiyah kota Semarang melakukan pembukaan informasi privat didorong oleh doktrin dalam Jemaat Ahmadiyah itu sendiri yang mewajibkan setiap Jemaat menyampaikan berita tentang kedatangan Imam Mahdi. Kewajiban menyamapaikan informsi ini bukan hanya menjadi tanggung jawab muballigh, semata, namun tugas ini juga dibebankan kepada setiap Jemaat.

\footnotetext{
${ }^{18}$ Wawancara dengan Endang Syafi'i sebagai Ketua Lajnah Imailah, Semarang: 7 Februari 2016 jam 21.18 WIB.

${ }^{19}$ Pahuluan, Alvan, 2016, (wawancara dengan Alvan Pahuluan sebagai anggota Jemaat Ahmadiyah), Semarang: 30 Januari 2016 jam 18.13 WIB.

${ }^{20} \mathrm{Ibid}$, wawancara.

${ }^{21}$ Wawancara dengan Dodik Setiawan sebagai Jemaat Ahmadiyah, Semarang: 18 Maret 2016 jam 13.30 WIB.

${ }^{22}$ Ibid, wawancara.

${ }^{23}$ Wawancara dengan Dodik Setiawan sebagai Jemaat Ahmadiyah, Semarang: 18 Maret 2016 jam 13.30 WIB.

${ }^{24}$ Ibid, Wawancara.
} 
Hal inilah yang membuat Jemaat Ahmadiyah di kota Semarang terus menyampaikan informasi mengenai status mereka sebagai anggota Jemaat Ahmadiyah maupun informasi mengenai doktrindoktrin yang terdapat dalam Ahmadiyah. Meskipun di satu pihak MUI melarang setiap bentuk pembukaan informasi tersebut.

Di samping itu Jemaat Ahmadiyah kota Semararng menyampaikan informasi privat mengenai Ahmadiyah juga bertujuan untuk melakukan klarifikasi atas apayang mereka sebut sebagai kesalahpahaman mengenai Ahmadiyah. Kesalahpahaman tersebut di antaranya terkait dengan tuduhan bahwa Jemaat Ahmadiyah memiliki kitab suci yang bernama Tadzkirah, Jemaat Ahmadiyah tidak melakukan ibdah haji ke Mekah tapi ke Qadian, dan lain sebagainya.

Pembukaan sebagai upaya klarifikasi ini dilakukan di antaranya oleh informan yang bernama Dodik Setiawan ketika dalam sebuah seminar Jemaat Ahmadiyah dikatakan sesat karena memiliki kitab suci bernama Tadzkirah. Peristiwa itu mendorong Dodik menyampaikan statusnya sebagai anggota Jemaat Ahmadiyah dan posisi Tadzkirah dalam doktrin Jemaat Ahmadiyah. ${ }^{25}$

Petronio mengatakan bahwa individu terdorong untuk menyampaikan informasi privat untuk membangun kepercayaan dalam sebuah hubungan, untuk mengurangi beban ketika individu tersebut sedang mengalami stress dan gangguan psikologis, dan karena adanya rasa ingin tahu yang sangat besar, permintaan, serta desakan yang dilakukan secara terus menerus oleh orang lain. Sedangkan beberapa alasan yang membuat seorang individu memutuskan untuk menutup informasi privat yang dimilikinya, yaitu karena takut keberadaannya ditolak oleh orang-orang di sekitarnya, individu tersebut takut membuat psikologis orang lain menjadi terganggu, serta individu tersebut tidak ingin merusak perannya sebagai figur yang pantas untuk diteladani individu tersebut tidak memiliki kebutuhan untuk terbuka terhadap orang tersebut. ${ }^{26}$

\section{B. Bentuk-Bentuk Penyampaian Informasi Privat}

Jemaat Ahmadiyah kota Semarang melakukan dua bentuk pengungkapan informasi privat yaitu melalui komunikasi langsung dan komunikasi tidak langsung. Dua cara ini dilakuakn sesuai dengan situasi dan kondisi yang sedang mereka alami. Dalam kondisi-kondisi terentu mereka melilih menyampaikan informasi privat mengenai Ahmadiyah secara langsung, namun dalam situasi yang lain mereka memilih melkuakan komunikasi dengan cara tidak langsung.

Komunikasi langsung dilakukan ketika Jemaat Ahmadiyah diundang menghadiri forum-forum tertentu seperti seminar, dialog, maupun diskusi publik. Beberapa informan menyampaikan kepada peneliti bahwa mereka selalu mengatasnamakan Ahmadiyah ketika mengahadiri forumforum tersebut. Biasanya dalam forum itu ketika mereka mendapatkan kesempatan untuk berbicara maka kesempatan tersebut dipergunakan untuk menyampaikan informasi-informasi mengenai Ahmadiyah.

Oleh karena itu informasi privat mengenai sebagai personal autonomy sengaja mereka bagikan kepada orang ghair sebagai bentuk klarifikasi atas apa yang mereka sebut sebagai kesalahpahaman tentang Ahmadiyah. Ketika Jemaat Ahmadiyah mengungkapkan informasi privat tersebut secara langsung, ada kesan yang mereka harapkan tumbuh pada orang lain mengenai Ahmadiyah.

Sementara itu salah satu cara Jemaat Ahmadiyah kota Semarang menyampaikan informasi privat secara tidak langsung yaitu dengan menunjukkan tingkah perilaku positif baik di lingkungan kerja maupun lingkungan sosial bersama masyarakat. Misalnya seperti yang dilakukan oleh Alvan Pahuluan. Ia mengatakan bahwa di kantor tempatnya bekerja ia selalu datang paling awal. Selain itu ia juga tidak pernah menolak pekerjaan yang diberikan oleh atasan

\footnotetext{
${ }^{25}$ Wawancara dengan Dodik Setiawan.

${ }^{26}$ West, Introducing, h.196.
} 
kepadanya. Ketika waktu shalat tiba ia juga selalu menjadi orang pertama yang bergegas ke Masjid. Cara-cara seperti ini menurutnya sangat ampuh untuk mengundang simpati dari rekanrekan kerjanya.

Pesan yang secara tidak langsung ingin ia sampaikan kepada rekan-rekan kerjanya adalah Jemaat Ahmadiyah merupakan orang-orang yang disiplin dan memiliki etos kerja tinggi. Bukan seperti apa yang selama ini dipersepsikan oleh sebgaian orang mengenai Jemaat Ahmadiyah yang dianggap sebagai kumpulan orang-orang sesat dan menyesatkan. Cara inilah yang dlakukan oleh Alavan Pahuluan di lingkungan kerjanya.

Jemaat Ahmadiyah kota Semarang juga menyampaikan informasi mengenai Ahmadiyah dengan menunjukkan photo-photo Mirza Ghulam Ahmad serta khalifah-khalifah Ahmadiyah yang lain di ruang tamu mereka. Hal ini dilakukan untuk mencari perhatian dan memancing pertanyaan dari orang-orang ghair yang bertamu ke rumah mereka. Dengan adanya ketertarikan maka mereka akan bertanya mengenai poto-poto tersebut. Kesempatan seperti ini mereka gunakan untuk membagi secara langsung informasi mengenai Ahmadiyah.

Cara ini terbukti cukup efektif untuk menarik perhatian orang-orang ghair. Hal itu dibenarkan oleh salah satu informan ghair yang bernama Rustam. Ia mengatakan awalnya mengenal Ahmadiyah dari tetangganya lewat poto-poto yang dipajang di ruang tamu. Setelah melihat potopoto yang menurutnya asing tersebut ia kemudian bertanya mengenai poto tersebut, dan Endang kemudian menjelaskan bahwa poto tersebut merupakan poto khalifah Jemaat Ahmadiyah. Endang kemudian menjelaskann lebih rinci tentang apa itu Jemaat Ahmadiyah beserta doktrin-doktrin yang terkandung di dalamnya. Rustam menceritakan:

"Taunya kan di rumahnya itu kan ada poto-poto, terus kita tanya itu poto siapa, terus dia menerangkan gini-gini gitu, poto-poto yang dipercaya dia lah, kebanggannya gitu. Aku jadi tahu ibu arif itu Ahmadiyah itu ya di situ., 27

Di samping itu Jemaat Ahmadiyah juga menyampaikan informasi mengenai Ahmadiyah dengan mengundang orang-orang ghair mengikuti khutbah yang disampaikan oleh Khalifah Mirza Masroor Ahmad setiap hari jum'at pukul 20.00 WIB. Ghair yang diundang untuk mengikuti acara ini biasanya dari kalangan mahasiswa, serta rekan-rekan kerja memiliki ketertarikan tersendiri mengenai Ahmadiyah. Beberapa pihak yang pernah peneliti temui ketika mengikuti khutbah khalifah itu di antaranya: mahasiswa UIN Walisongo, Mahasiswa UIN Sunan Ampel, Universitas Airlangga, Pegawai Bank Mandiri Ungaran, serta beberapa orang karyawan Suara Merdeka.

Selama penelitian ini berlangsung, peneliti selalu mengikuti kegiatan khutbah khalifah tersebut. Dari situ peneliti mengetahui bahwa cara ini memang merupakan salah satu bentuk pembukaan yang mereka lakukan kepada ghair. Sebab setelah khutbah disampaikan, biasanya Jemaat Ahmadiyah kota Semarang kemudian mengajak ghair berdiskusi seputar doktrin Ahmadiyah. Dalam moment inilah mereka mengenalkan Ahmadiyah secara panjang lebar kepada ghair.

Setelah melakukan beberapa bentuk pengungkapan itu Jemaat Ahmadiyah kota Semarang berharap, paling tidak orang lain akan mendapatkan pemahaman yang utuh tentang Ahmadiyah dari sumber aslinya, kemudian dapat pula meneruskan informasi tersebut kepada ghair.

\section{Cara Mengontrol Informasi Privat}

Jemaat Ahmadiyah kota Semarang melakukan kontrol atas informasi privat mereka dengan cara memilih siapa saja yang dapa mengakses informasi privat tersebut. Mereka melakukan seleksi yang cukup ketat dengan beberapa indikator sebelum menyampaikan informasi privat mereka.

\footnotetext{
${ }^{27}$ Wawancara dengan Ibu Rustam, Semarang: 14 Maret 2016 jam 16.38 WIB.
} 
Kepada orang-orang dari kalangan Nahdlatul Ulama (NU) Jemaat Ahmadiyah kota Semarang justru membagikan informasi mengenai Ahmadiyah. Salah satu informan yang bernama Dodik mengatakan bahwa ia sering melakukan pengungkapan pribadi kepada orang-orang Nahdlatul Ulama (NU). Menurutnya orang-orang NU adalah kelompok yang toleran terhadap Jemaat Ahmadiyah kota Semarang. Informan lain yang bernama Agus Supriyanto juga mengaku awalnya adalah seorang nahdliyyin.

Fakta ini menarik untuk ditelusuri sebab NU sendiri pada dasarnya menolak keberadaan Ahmadiyah. ${ }^{28}$ Di kota Semarang sendiri, berdasarkan hasil penelitian yang dilakukan oleh M. Aris Rofiqi seorang mahasiswa pascasarjana UIN Walisongo Semarang dalam tesisnya yang berjudul "Respon Ulama NU Semarang terhadap Fatwa MUI tentang Pelarangan Ahmadiyah", menunjukkan bahwa ulama NU yang berada di kota Semarang memandang bahwa Ahmadiyah merupakan aliran sesat dan menyesatkan. Hal ini terutama sekali berkaitan dengan doktrin Ahmadiyah yang meyakini adanya Nabi setelah Nabi Muhammad. ${ }^{29}$ Pandangan ulama NU di kota Semarang ini sejalan dengan fatwa yang dikeluarkan oleh MUI tentang Jemaat Ahmadiyah.

Selain kepada NU, peneliti juga menemukan bahwa Jemaat Ahmadiyah kota Semarang juga menyampaikan informasi megenai Ahmadiyah kepada aparat pemerintah. Pembukaan ini bertujuan untuk memberi masukan kepada pemerintah terkait bagaimana pola pembinaan kerukunan ummat beragama di Kota semarang. Di samping itu dengan membangun komunikasi dengan aparat pemerintah, Jemaat Ahmadiyah juga berharap mendapatkan jaminan keamanan ketika melaksanakan kegiatan-kegiatan yang berkaitan dengan Ahmadiyah.

Tugas membangun komunikasi lintas organisasi ini dibebankan kepada Sekretaris Umur Kharijiah. Tugasnya antara lain mengagendakan pertemuan antara Jemaat Ahmadiyah kota semarang dengan ormas-ormas seperti NU, Komunitas Lintas Iman, Gereja, maupun LBH, perguruan-perguaran tinggi, serta aparat pemerintah kota Semarang.

Peneliti melihat ada kecenderungan jemaat Ahmadiyah lebih terbuka terhadap kelompokkelompok yang toleran terhadap Ahmadiyah sekalipun kelompok tersebut berasal dari luar Islam. Hal ini dibuktikan dengan seringnya mereka diundang sebagai pembicara dalam diskusi-diskusi yang dibuat oleh komunitas gereja. Padahal menurut muballigh Ahmadiyah kedatangan imam Mahdi (Mirza Ghulam Ahmad) adalah untuk mematahkan salib (menginvansi agama kristen).

Sementara itu Jemaat Ahmadiyah kota Semarang tidak membuka informasi kepada kelompokkelompok yang dinilai tidak satu visi dengan mereka dan sering melakukan penentangan terhadap Ahmadiyah. Menurut mereka, yang masuk dalam kategori ini adalah kelompok Islam garis keras itu seperti Front Pembela Islam (FPI), Jemaah Anshorut Tauhid, dan LDII, begitu juga kader dan Partai Keadilan Sejahtera (PKS). Menurut mereka para politisi PKS sering melakukan penolakan secara langsung terhadap gerakan Jemaat Ahmadiyah.

Muhammadiyah sebagai salah satu ormas Islam terbesar yang ada di Indonesia bagi Jemaat Ahmadiyah kota Semarang masuk dalam kategori kelompok yang tidak diberikan akses untuk mengetahui informasi mengenai Ahmadiyah. Hal ini didasari oleh perlakuan kurang baik yang mereka dapatkan ketika menghadiri acara milad yang dilaksanakan oleh Pengurus Wilayah Muhammadiyah Jawa Tengah.

Peneliti mengkonfirmasi berita ini kepada Fahrurrozi selaku Pengurus Daerah Muhammadiyah kota Semarang. Kepada peneliti ia mengatakan bahwa persoalan Ahmadiyah bagi

\footnotetext{
${ }^{28}$ Sikap resmi NU ini peneliti kutip dari laman http://www.nu.or.id/post/read/12315/sikap-pbnu-tentang-ahmadiyah , terdapat empat poin utama yang menjadi sikap NU terhadap Jemaat Ahmadiyah: Pertama, NU menyatakan Ahmadiyah adalah aliran sesat dan keluar dari Islam. Kedua, Protes terhadap Jemaat Ahmadiyah harus dengan cara-cara yang sopan. Ketiga, Ummat Islam diharapkan belajar Islam secara komprehensip agar tidak mudah keliru. Keempat, NU meminta pemerintah bersikap tegas dan konsisten menyikapi keberadaa Jemaat Ahmadiyah di Indonesia.

${ }^{29}$ Rofiqi, M. Aris, 2007, Respon Ulama NU Semarang terhadap Fatwa MUI tentang Pelarangan Ahmadiyah, Tesis, Semarang: UIN Walisongo, h.110.
} 
Muhammadiyah sudah final. Muhammadiyah kota semarang secara tegas menentang ajaran dalam Ahmadiyah, terutama sekali menyangkut masalah kenabian. Sebab bagi Muhammadiyah nabi Muhammad merupakan nabi terkahir dan tidak ada lagi nabi setelahnya. ${ }^{30}$

Tetapi secara hubungan kelembagaan Muhammadiyah kota Semarang mengatakan tetap bersikap baik kepada pihak manapun, termasuk kepada kelompok Jemaat Ahmadiyah yang berada di kota Semarang. Hal ini dilakukan salah satunya dengan cara mengundang Jemaat Ahmadiyah kota Semarang menghadiri acara yang dibuat oleh Pengurus Daerah Muhammadiyah kota Semarang.

\section{Kesimpulan}

Berdasarkan analisa yang peneliti lakukan terhadap jemaat Ahmadiyah kota Semarang dengan menggunakan teori manajemen komunikasi privasi pada bab sebelumnya, peneliti dapat meenyimpulkan bahwa pembukaan informasi yang dilakukan oleh Jemaat Ahmadiyah dalam rangka menyebarluaskan doktrin Ahmadiyah ke suluruh pelosok dunia. Dengan melakukan pembukaan secara langsung dan tidak langsung Jemaat Ahmadiyah terbukti efektif menarik simpati dari ghair. Hal ini dibuktikan dengan terus bertambahnya jumlah anggota jemaat Ahmadiyah kota Semarang dari waktu ke waktu.

Pola-pola komunikasi yang dilakukan oleh Jemaat Ahmadiyah dengan membuka dan menutup informasi mereka serta melakukan seleksi terkait siapa saja yang dapat mengakses informasi privat tersebut menunjukkan bahwa mereka tengah melaksanakan dakwah secara tersembunyi (sirriyah). Upaya-upaya dakwah semacam semacam ini dilakukan dalam rangka merespon fatwa yang dikeluarkan oleh MUI tentang pelarangan seluruh aktifitas penyebaran ajaran Ahmadiyah.

\section{DAFTAR PUSTAKA}

Amrullah, Moh. Asyiq, dkk, 2010, "Dampak Sosial Kekerasan Terhadap Jamaah Ahmadiyah di Lombok dan Upaya Resolusi Konflik”, Jurnal Penelitian Keislaman, Vol.6 (6), 54-67.

Arifin, Anwar, 2011, Dakwah Kontemporer: Sebuah Studi Komunikasi, Yogyakarta: Graha Ilmu.

Petronio, Sandra, 2002, Boundaries of Privacy: Dialectics of Disclosure, New York: State University of New York Press.

Rofiqi, M. Aris, 2007, Respon Ulama NU Semarang terhadap Fatwa MUI tentang Pelarangan Ahmadiyah, Tesis, Semarang: UIN Walisongo.

Rosyidin dan Mursyid Ali, 2007, "Diskriminasi Hak Sipil Minoritas: Pelarangan Pencatatan Pernikahan jemaat Ahmadiyah Kuningan" dalam Ahmad Suaedy dkk. Politisasi Agama dan Konflik Komunal: Beberapa Isu Penting di Indonesia, Jakarta: The Wahid Institute, 49-75.

Zulkarnain, Iskandar, 2005, Gerakan Ahmadiyah di Indonesia, Yogyakarta, LKiS

Dirjen Bimas Islam dan Penyelenggaraan Haji Kementrian Agama Republik Indonesia, Himpunan Fatwa Majelis Ulama Indonesia, Jakarta 2005.

Keputusan Bersama Menteri Agama, Jaksa Agung, dan Menteri Dalam Negeri Republik Indonesia Tentang Peringatan dan Perintah Kepada Penganut, Anggota, dan/atau Anggota Pengurus Jemaat Ahmadiyah Indonesia (JAI) dan Warga Masyarakat. Jakarta, 2008.

Syafi'i, Arif, 2016, (wawancara dengan Arif Syafi'i sebagai Ketua Jemaat Ahmadiyah Jawa Tengah), Semarang: 17 Januari dan 3 Maret 2016 jam 18.33 WIB.

\footnotetext{
${ }^{30}$ Wawancara dengan Fahrurrozi, Pengurus Daerah Muhammadiyah Kota Semarang, Semarang: 20 Juni 2016 jam 08.45 WIB.
} 
Supriyanto, Agus, 2016, (wawancara dengan Agus Supriyanto sebagai Ketua Jemaat Ahmadiyah kota Semarang), Semarang: 11, 17 Januari jam 16.00 WIB dan 1 Februari 2016 jam 18.10 WIB.

Syafi'i, Endang, 2016, (wawancara dengan Endang Syafi'i sebagai Ketua Lajnah Imailah), Semarang: 7 Februari 2016 jam 21.18 WIB.

Setiawan, Dodik, 2016, (wawancara dengan Dodik Setiawan sebagai Jemaat Ahmadiyah), Semarang: 18 Maret 2016 jam 13.30 WIB.

Pahuluan, Alvan, 2016, (wawancara dengan Alvan Pahuluan sebagai anggota Jemaat Ahmadiyah), Semarang: 30 Januari 2016 jam 18.13 WIB.

Rustam, 2016, (wawancara dengan Rustam sebagai co-owner Endang Syafi'i), Semarang: 14 Maret 2016 jam 16.38 WIB.

Fahrurrozi, 2016, (wawancara dengan Fahrurrozi sebagai Pengurus Daerah Muhammadiyah Kota Semarang), Semarang: 20 Juni 2016 jam 08.45 WIB. 